\title{
Figurative Disconnection(s) in Eldorado by Laurent Gaudé
}

\author{
Daniel Tia \\ Department of Modern Literature, French Literature, \\ University of Felix Houphouet-Boigny \\ Abidjan-Cocody, Cote d'Ivoire \\ *Corresponding author details: Assistant Professor Daniel Tia; \\ yawejanet@yahoo.com
}

\begin{abstract}
A retrospective glance at the history of humankind discloses that disasters are consubstantial to human existence. From ancient times to our era, no centennial interlude unfolded without dreadful and sad incidents. Despite the improvement of educational sectors to provide humans with adequate training, their perfection remains controversial -their radical and deviationist behaviors keep on bringing about unprecedented tensions, humanitarian and ecological crises. Human relations have turned more tumultuous than ever. No one seems to listen to the other, be in harmony with themselves and their environment. Things occur as if humans were both uneducated and uncivilized. The 21st century suffers from a procession of disastrous events, which unfortunately illustrate humans' loss and disharmony with themselves and other living beings. Unable to resolutely bring palliative response to the drawbacks of their own deeds, they wander, seeking uncertain and utopian landmarks, which unfortunately worsen their living conditions. They enter this century not as conscious subjects, but rather as crispy individuals, for they have lost their rational faculties, educational and civilizational values. The occurrence of abusive exploitation of forest and halieutic resources in Eldorado, illustrates their sinful and cruel actions against nature and non-human animals. With reference to those devastating actions, it is relevant to guide and reorient their attitude in order to help the present and future generations avoid chaotic or dramatic situations. To that end, it is essential to question figurative disconnection(s) in Laurent Gaudé's novel. The use of ecocritic approach will contribute to elucidate a literary project, which advocates awareness, universal humanism and the revision of humans' behavioral habits towards their environment.
\end{abstract}

Keywords: universal humanism; halieutic resources; nature; disconnection; reconnection; non-human animals

\section{INTRODUCTION}

Born in the second half of the 20th century (1972), Laurent Gaudé is a French writer whose novels have overcome any canonical shackles and sectarian practices by crossing physical and imaginary borders. His creative art textualizes the events of his continent of origin as well as those of other cultural backgrounds. Some of his texts incorporate mythical values and wars, which have been devastating various world societies. Others thematize the painful and dramatic realities, which presently beset Europe, Asia, and Africa. Under a double angle, Gaudé depicts illegal immigration, conflicts, epidemics, and environmental crises.

On the one hand, he decries humans' irresponsible behaviors. Despite the educational progress, they behave as harmful agents, capable of destroying their own environment and that of the future generations. On the other hand, Gaudé's novel promotes a global awareness (Europe and elsewhere), abandonment of retrograde habits to save the countries whose citizens desperately leave their homelands and seek refuge in other tropics in search of fortune -a commodity, which is scarce in their homelands. From a humanist perspective, Gaudé's Eldorado evokes some issues whose definitive and integral resolution could symbolize the onset of a new era heralding the advent of peaceful, harmonious, selfreconciled societies.
Let us underline that disconnection between, humans and their environment, past and present, humans and animals, political rulers and their people, humans and their cultures are some of the figures constructed by Gaudés fictional work. Those values intend not to please and inform the author's readership, but rather to draw European, Asian, and African decision-makers' attention on human tragedies and other disasters of the 21st century whose emergence discredits the sense of humanity of today's world citizens. Gaudé's Eldorado raises awareness and decries European environmental policies and migration management. In terms of substance, the novel under consideration prevents crises, which threaten today's world populations and those to come. In accordance with the issue of disconnection(s), the current study is interested in one aspect, which illustrates ecological crises. However, before examining that specific point, we propose to present some of the critical works already done on Eldorado.

As such, let us consider Silvia U. Baage's "Regards exotopiques sur deux portes de l'Europe : la crise migratoire à Lampedusa et à Mayotte dans Eldorado et Tropique de la violence" (2017). This critical work examines the despair of several migrating individuals. To Baage, Europe is regarded as an Eldorado (place where human fulfilment is possible); however, what they experience on their way to Europe is pitiful (death, ill-treatment, anger, and imprisonment). 
Besides, Gary D. Mole's “Mordre la poussière dans l'Eldorado à rebours: Laurent Gaudé, la migration clandestine et l'ombre de Massambalo" (2019) is interested in Gaudé's narrative techniques. To Mole, since 2000, Francophone literature (literature written in the French language) has been incorporating themes, namely migrance, nomadism, exile, diasporization, miscegenation, hybridity, transculturality, and multiculturality. To him, Francophone literature is profoundly interested in migrants' sufferings. Further, Aurélie Palud's “Trajectoires contemporaines : traverser la Méditerranée dans le roman du XXIème siècle" (2020) explains "the way in which the contemporary novel stages the crossing of the Mediterranean, from South to North, from North to South" (Palud, 2020). In addition to the above critical work, Daniel Tia's "Contrast of Visions in Paule Marshall and Laurent Gaudé's Novels" (2021) questions the visions of pure-born Africans and African Diaspora. Through a comparative semiotics, he concludes that no society is exclusively free from troubles. Through the issue of relativity, he considers Gaudé's novels as an invitation addressed to European, African, and Asian decision-makers to solve illegal immigration and its related troubles.

As we can notice, from 2006 (date of publication of Gaudé's novel) up to now, Eldorado has been interrogating by various literary critics. The above review shows that Gaudé's literary project claims a universal humanism, which is expressed through human and environmental disconnections. To be successful, this study will be based on an analytical dynamism, which consists in moving from the surface (collecting textual clues), to the depth (interpreting those data). With reference to that methodological technique, the use of ecocriticism will be essential and helpful. To Cheryll Glotfelty and Harold Fromm, "nature per se is not the only focus of ecocritical studies of representation. Other topics include the frontier, animals, cities, specific geographical regions, rivers, mountains, deserts, Indians, technology, garbage, and the body" (Glotfelty and Fromm, 1996). Clearly, leaning on the principles of that methodological guide, the current study will question the textual clues related to the picture of immigrant and nature. Three points will be examined, namely disconnection between humans and environment, disconnection between humans and animals, and a plea for a humanist/Christianist reconnection.

\section{DISCONNECTION BETWEEN HUMANS AND ENVIRONMENT}

To analyze this section, we will take into account humans' contempt towards nature (forest), sea, and environment.

Before examining those textual values, let us note that disconnection is apparent through the characters' irregular and contemptuous attitudes. Migrating characters whose words and deeds are incorporated in Eldorado, illustrate hatred towards nature. They are the first destructive agents of flora. To Charlie Flores, "after millennia of disconnection, we have reached a point in time in which we are finally realizing the impact that our actions have had on the natural world" (Flores, 2019). Indeed, to cross the border between Morocco and Ceuta (Spain), African migrants cut down trees to make ladders, which could help them climb the wall, separating Morocco from Spain. That wall represents the border between Africa and Europe. By destroying the forest, those migrants negatively influence nature. A close glance at their attitudes reveals that what is relevant for them is to cross the border at any costs.

In essence, they are no longer willing to return to their respective birthplaces. This means they consider Africa as a hellish continent. Soleiman, one of Gaudé's migrating characters reveals, "the sun of happy days will warm our blood and the memory of horror will keep us from regret" (Gaudé, 2006). Noticeably, the migrants' main dream is to leave Africa and never come back again. Certainly, some feel anxious, but their anxiety is mainly related to their lives to come. It does not matter whether they harm Africa or not. All their thoughts are oriented towards their future host society. More importantly, they define themselves as full-fledged Europeans. Their current and urgent dream is to settle in Europe and construct a new social identity. Indeed, the desired identity for which they strive is projected into the future. As described in the novel under consideration, that identity will participate in the migrating characters' social integration. Therefore, to fulfill their dream, they violate the bound between humans and nature. Through their retrograde and hateful deeds towards nature, we can infer that Gaudé's migrating characters illustrate themselves as rebels, uncivilized beings. They despise their own societies, which have raised them and do not consider nature as a wealth, which is consubstantial to humans' lives in Africa as well as elsewhere.

It should be noted that Gaudé's migrating characters are eager to leave Africa. To them, their continent is less promising. This means they ignore all values related to plant species. Describing migrants' irregular behavior, Gaudé's narrator asserts, "let us not waste time. We must build the ladders. Therefore, in the forest of our clandestinity, a huge construction site begins. We cut the branches, prune, cast. Makeshift ladders are born in the hollow of our arms. We have to make them solid and high. It is on them that we will take support for the big jump. It is on their solidarity that our future life will depend. If they break, we are condemned once again to wait in the desert. If they hold, we will tread the land of our dreams. We will put all our attention and our art in the construction of those ladders. They are growing everywhere. Everyone wants their own. We must be able to line the barbed wire with them" (Translation mine) (Gaudé, 2006). This quotation depicts African migrants' cruel attitudes towards flora. Here, Eldorado points out a form of disconnection, which shows that the migrants have lost track of time. And now, they believe to be allowed to do anything, provided that they achieve their desired goal. African vegetation communities appear insignificant to them. They consider them as their properties. To Charlie Flores, "what we can do, and what I believe is imperative to do, is to provide people with thought experiments and provocations to challenge their ideas on our relationship with nature. Helping people understand and think critically about our true place in nature is a step towards societies with better relationships with nature, like those of the indigenous tribes of the Americas" (Frances, 2019). Clearly, Gaudé's migrating characters do not find any advantage to take care of them -their new favorite place is Europe.

Besides, Moroccan soldiers' aggressive behaviors are illustrative of disconnection between humans and their environment. Indeed, through their fight against illegal immigration, they sin against nature. By hunting down African migrants, they set fire to the forest, which serves as their hiding place. Not only do their deeds contribute to the destruction of flora, but they also denote Moroccan soldiers' irresponsibility and contempt towards nature. Through their stalking strategies, their lack of professionalism turns more apparent. Gaudé's novel describes their crime as follows, "last time, they swooped down on us like ravenous bees. In the middle of the night. The headlights of their cars came on at the same time and they jumped out of their Jeeps screaming, bludgeoning anybody they found on their path. In an instant, we were in a panic. 
Everyone was looking for their bag, their blanket, a shelter or protection from the blows. However, they came in numbers. They hit and threw their dogs to flush us out like game. Then, they set fire. They had never done that before. They sprayed gasoline on the bags they found, the bushes. They burned everything. It is then that Boubakar extends his finger towards the night, towards the hill where we used to hide. 'Look!', he says. I see little orange lights flickering in the night. More and more. It is burning. They just set fire to our camp. The flames are getting higher and higher" (Translation mine) (Gaudé, 2006).

In the above passage, the narrator relates his painful experiences and those of his fellow migrants during their voyage to Europe. A meticulous analysis of his words helps us discover that he is involved in his discourse. Talking about the African migrants' sufferings, Gaudé's narrator discloses two levels of disconnection. One is related to the Moroccan soldiers' hatred and inhospitality towards the migrants. The other is about the unpleasant treatment inflicted upon the forest. Indeed, Moroccan soldiers behave as if the forest had no importance in human life; they rape its virginity (destroy its natural beauty) without worrying about its relevance in their people's lives. As romanticized by Gaudé, the forest protects Moroccan borders. In addition to that, it provides rain and other vital substances for the Moroccan people. However, both African migrants and Moroccan soldiers overlook those values and negatively influence nature. As a response to those crimes, Eldorado decries Moroccan environmental policy. To the author, Moroccan soldiers' deeds on the ground are intolerable. Through their picture, Eldorado blames them for their cruelty. To Gaudé, the Moroccan soldiers' deeds are motivated; they receive orders from their authorities. This means they are involved in the disaster, which happens on the ground. Significantly, Gaudé's text criticizes the authorities' incapacity to protect the African migrant and their environment (forest).

Significantly, disconnection is an act of separation, abandonment, rupture, and rejection, which can be voluntary or forced. In Eldorado, disconnection is shown through the irresponsible behaviors of Gaudé's migrating characters. Indeed, during their voyage to Europe, some of them perish due to dehydration. Thus, their lifeless bodies are thrown into the sea. A priori, that action illustrates disconnection. Migrants who are still alive feel compelled to get rid of the bodies of their fellow migrants to avoid being contaminated. However, by throwing those bodies into the sea, they deteriorate the aquatic space, thus corroborating humans' contempt towards their environment (nature). The ensuing passage faithfully renders that tragedy, "the first death was an Iraqi in his twenties. At first, no one knew what to do; then the men decided that the bodies should be thrown into the sea. To make room and avoid any risk of epidemic. Soon, the number of bodies thrown into the water increased" (Translation mine) (Gaudé, 2006). Explicitly, the figurative field of disconnection is related to humans' transgressive attitudes.

Substantially, by getting rid of the migrants' bodies, the survivors commit a double sin. Indeed, the rotting bodies thrown into the sea pollute the maritime zone, endangering both migrants and Europeans' health. The narrator indicates that most of the bodies wash up on the beaches. This causes an environmental crisis, for the beaches turn a graveyard. Worse still, the ambient air is polluted. The following passage shows how the migrants and the Moroccan soldiers contribute to the destruction of nature in Gaudé's fictional society, "at the beginning, the inhabitants of Lampedusa saw these boats of misery arrive with amazement. The sea regularly brought them some bodies and they were upset" (Translation mine) (Gaudé, 2006). As a result, the populations of Lampedusa leave the beaches. In terms of economic asset, this appears as a severe blow, for tourist activities drastically decrease. As described in the above citation, Gaudé's fictional universe is in crisis, for the migrating characters no longer commune with nature. They have abandoned it; they no longer take care of their environment. Some aquatic species disappear because of humans' irresponsibility towards nature.

Worse still, the air smelt by Europeans is unpleasant. For instance, in the ensuing textual clue, one of Gaudés narrators provides a deprecating picture of an Italian City, "in Catania, on this day, the pavement the alleys in the Duomo District smelt fish" (Translation mine) (Gaudé, 2006). Importantly, migrants originating from various cultural backgrounds, saturate Catanian space (Italian city). Consequently, its environment is polluted. Symbolically, the image drawn from that portrayal, contradicts the ideals inscribed in the title Eldorado. This means Europe is not a space where everything is positive. Through the degradation of Catania, Gaudé's novel discloses that Europe is confronted with an environmental crisis whose roots are in humans' contemptuous attitude towards nature. Recognizing that today's environmental crisis, Charlie Flores argues, "one of the main problems in our society that has resulted in negative consequences at the expense of the natural world is the concept of ownership of land. The concept of private property in terms of land is not something that is or was practiced by every culture. In pre-colonial America, many of the native peoples living in the Americas did not have a concept of private property. One could not own land the way our society does. Many native peoples also saw animals as equals. Animals would only be hunted for food, and the hunter would ask the animal's spirit permission to kill it" (Frances, 2019).

When analyzing figurative disconnection, interest was given to the connection between humans and nature. The study of that value has pointed out how "nature suffers" from human activities. This has been considered as a jeopardy for both humans and nature. In Gaudé's novelistic world, there is also figurative disconnection between humans and animals, which the following section aims to examine.

\section{DISCONNECTION BETWEEN HUMANS AND ANIMALS}

This section is interested in another aspect of disconnection, which is based on the tumultuous and fragile connections between humans and animals. Gaudé's novel presents Catania (Italy) as a metaphor of human decay. Indeed, Catanian fishermen are involved in an overexploitation of fish resources, which illustrates their lack of interest in animals. As depicted by Gaudé's narrator, fishing activity is Catanians' main source of income. Nevertheless, when it comes to trading, Catanian merchants are sometimes overflown with fish. This means they fail to sell all their products. Accordingly, the latter spread them out all over the city to dry them. The narrator confesses, "on the tight stalls of the market, hundreds of tuna fish shone in the midday sun. From the buckets on the ground, men emptied them with a dry gesture. The tuna and swordfish were displayed like precious trophies" (Translation mine) (Gaudé, 2006). Through description, comparison, and exaggeration, Eldorado decries the excessive exploitation of fish. Those narrative techniques show that Catanian fishermen have no consideration for animals (fish).

Further, let us note that overfishing depletes the sea of halieutic resources. To avoid an eventual destruction of the 
aquatic fauna, it essential to preserve its resources. To that end should be advantageous to practice modern fishing, which exhorts the rational exploitation of the aquatic reserve. In practice, modern fishing preserves and protects a number of rare species of aquatic fauna; it also avoids fishing fry. Examining the issue of disconnection between humans and nature, Charlie Frores avows, "indeed, the mesh size of the fishing nets should be large enough to allow the fry to slip through the mesh openings. This can avoid harmful influences on the sea. By taking care of the sea, it can remain Europeans' foster mother. Nevertheless, Gaudé's novel describes a disproportionate practice, which attests that the fishermen operating on Italian coasts do not care about the dramatic consequences of their deeds. Indeed, through their maritime activities, we discover that their actions can annihilate certain species of fish; no preventive measures are taken. Gaudé's narrator describes their contempt as follows, "it was as if the waters had slipped through the alleys at night, leaving the fish as an offering at dawn. What had the people of Catania done to deserve such a reward?" (Translation mine) (Gaudé, 2006). Clearly, in the above utterance, novel presents a macabre and sad picture of Catania.

In reality, that city has received no award. From a legal point of view, the picture provided by the novel under consideration is disappointing. One of the author's narrator qualifies it as a sin. Catanian people systemically destroy of the aquatic fauna to satisfy their needs for their survival. Catania is flooded with fish; the saturation of Catanian market complicates and worsens business activities. As a result, Catanian merchants have no alternative outlet for their products. To Charlie Flores, "today, we are faced with pollution that traps more heat in the atmosphere than before, polluted waterways, and the depletion of animal populations that we feed off of, along with many other problems that have started at the fault of humanity. Our society is so disconnected from the natural world that there are people that still do not believe that we are causing harm to the natural world" (Flores, 2019). Notably, this situation brings about an environmental crisis, which is decried by Eldorado in the following citation, "in this day, still, the sea had given. There might be a time when fish would be found dead in the nets, or thin, or spoiled. The cataclysm is never far away. Humans have done so much wrong that no punishment can be excluded. The sea, one day, would perhaps starve them. As long as it offered, it was necessary to honor its gifts" (Translation mine) (Gaudé, 2006).

In the above example, nouns such as, "cataclysm" and "wrong" are illustrative of the figures from which, disconnection between humans and animals turns obvious. It is worth noting that humans do not share mutual love. Their lack of love, consideration, and respect toward animals makes them indifferent and hostile - they only think about their own interests. In other words, they do not feel any remorse related to their abusive exploitation of the aquatic fauna, provided that they raise enough material. Examining disconnection, Joanne Vining remains, "in our era in which natural resources are under unprecedented pressure, it is vital to ask how the human relationship with the human relationships with the natural world might be improved. A good starting point be to explore what is known about how caring relationships with nature develop" (Vining, 2003). A close glance at Gaudé's novel helps us discover that his characters' desire to immediately respond to their needs has transformed them. Metaphorically, they are criminals; as such, they deserve to be punished. To the narrator, the crimes committed by humans are uncountable; that is, they are passive of legal proceedings. Through the noun, "punishment," Gaudé's text draws his readers' attention on the tragedy, which appears on the horizon, inter alia the shortage of fish on the markets in the coming years and the destruction of aquatic species.

Besides, it is significant to supply European markets with fish, for Europeans need them for their survival; however, no control is imposed on maritime activities. In terms of management, there is a crucial slackness of halieutic resources. This makes possible the abusive exploitation of fish. With reference to that anarchic fishing, we can assert that the current situation is not only a threat to the living beings evolving in the sea, but also to humans. Indeed, in case of shortage of fish on the market, Europeans will suffer from it. Worse still, fish processing industry will be unable to keep on functioning. This can bring about unemployment. As a proof, the ensuing utterance is illustrative of a warning, "on this day, still, the sea had given. Perhaps there would be a time when she would refuse to open her belly to fishermen. Where the fish would be found dead in the nets, or thin, or spoiled" (Translation mine) (Gaudé, 2006). As we can see, Gaudé's narrative discourse transcends literary barriers and crystallizes in the political milieu. The author's fictional society undermines all readers. Humans, evolving there, exclusively consider the realities of their lifetime; they have no future projection related to the aquatic resources. Their rupture with the other living beings is representative of the disorder, from which Europe suffers. Indeed, the crises caused by migratory flow have turned so pronounced over time that the migrants' behaviors have changed in a negative direction.

Through the figure of smellscape, disconnection between humans and animals is also more tangible/obvious. Europeans no longer feel comfortable; the advent of an unpleasant era in both Catania and Lampedusa (Europe) worsens the inhabitants' lives. For instance, Catanian people turn reluctant to buy and consume fish, because of the pollution of the ocean. Indeed, the latter believe that the fish, which are caught in sea, eat the bodies, which are thrown into the sea. Accordingly, fish trade undergoes a severe crisis. In all the Catanian alleys, we can find the fish spread out. That exhibition emits a foul odor, thus polluting ambient air, thus influencing the Catanians. Even the Italian commander named Salvatore Piracci is one of the agents of the coast guard who is amazed by the gloomy era prevailing in both Catania and Lampedusa. One of Gaudé's narrators reveals the commander's feelings as follows, "Salvatore Piracci strolled through the alleys, slowly, letting himself be carried by the movement of the crowd. He observed the rows of fish laid out on the ice, dead eyes and open stomach. His mind was as if caught by this spectacle. He couldn't take his eyes off them and what for any other person was a joyful profusion of food seemed to him a macabre exhibition. He commits violence on himself to escape this vision" (Translation mine) (Gaudé, 2006). Plausibly, the above textual clue describes how alarming the deep-sea fishing is. Implicitly, Eldorado exhorts European political authorities to take actions, which can save the communities of aquatic animals. Eldorado shows that even the commander (Salvatore Piracci) is scandalized by that tragedy. His feelings are representative of the seriousness of the disconnection prevailing between humans and animals. The more that disconnection increases, the more the animals suffer.

In short, human society suffers from various crises. The one depicted by Gaudé's work is plagued by disconnection; its inhabitants are disconnected. The novel under consideration can be regarded as a catalyst with a double scope -on the one hand, it criticizes humans' deviant behaviors towards non-human animals. On the other hand, it promotes an awareness whose primary interest is the protection of nature and animals. 


\section{A PLEA FOR A HUMANIST/CHRISTIANIST RECONNECTION}

Is it necessary to encourage a reconnection between humans and nature? The answer to this question is the concern of this section. Two points will be developed here, namely the humanistic and religious aspects of reconnection.

On the humanistic level, Gaudé's novel plays a paramount role. Certainly, his text describes some desperate migrants, who have decided to leave their respective countries, but the aesthetic scope, which emerges from that pathetic picture, is profound. Indeed, to Gaudé's vision, humanism should not be a false act like the rescue of migrants, which is followed by confinement. Obviously, one should not condone the death of thousands of migrants. That is why Salvatore Piracci's words bear a humanist significance in the novel Eldorado, "we save lives. We go in search of lost men who would drown without our help or starve to death, men who hope for us with all the strength of their lives" (Translation mine) (Gaudé, 2006). Clearly, those acts of rescue should be praised. However, the paradox is the migrants who are rescued, are made prisoners and sent to detention after their rescue. This is what Gaudé's novel decries.

Once the migrants are rescued, they are arrested or sent to detention. To Gaudé, the acts of rescue are propagandized, giving the impression that Europe is playing a salutary role by rescuing African and Asian migrants, whereas in reality, one question remains unanswered: what happens to the rescued migrants? Western media ignores that question whose answer is provided by Gaudé's text as follows, "we look for men on the waves and as soon as we find them, we become strict policemen again. Under arrest. That's what they are waiting for. That I put them under arrest..." (Translation mine) (Gaudé, 2006). Apparently, the above utterance shows that Europe does not act as a promotor of true humanism. Its actions towards migrants are full of lies. Indeed, the old Sicilian, one of Gaudé's characters qualifies those lies as "oily speeches, lying speeches" (Translation mine) (Gaudé, 2006).

Obviously, Gaudé's novel requires a revision of habits, decisions, and visions about others (those who are not necessarily European). In other words, the kind of humanism promoted by Eldorado has a universal scope. The very one, which is advocated by Gaudé should be expressed towards the underdeveloped countries upstream and not downstream. In accordance, the author's vision, the lack of humanist long-term initiatives in those countries brings about massive exodus. Considering the seriousness of that situation, which heralds a bleak future, Eldorado exhorts a revision of European foreign policy. Salvatore Piracci, one of Gaudé's character reveals his disappointment as follows, "when I think of those men who look at the horizon with impatience and appetite, I envy them. I tell myself that I am only bad luck, the ugly face of bad luck. Those I catch are only a tiny part of those who attempt the crossing. Those I intercept are those who don't even have luck on their side. For twenty years, I have been walking my silhouette on the sea and I am the evil eye that tracks the desperate. It is from this that I am exhausted" (Translation mine) (Gaudé, 2006). To avoid such a trouble, it is relevant to personify the nature. Charlie Flores advises, "I believe that if personifying the Earth helps become more empathetic and considerate towards the Earth" (Flores, 2019).

In other words, the lack of consideration of nature and solidarity among humans is a source of various crises. Through the above utterance, Eldorado urges European, Asian, and African political authorities to promote frank humanism, based on respect for human and nature dignity. In that novel, Moroccan, Italian and Spanish soldiers' picture is a disgrace and a threat to Humans and nature's tranquility. Without fair reconnection between humans, without a dazzling universal humanism, values, such as respect for the other, cultural and intellectual development cannot flourish. Consequently, the ideals of globalization and those of environmentalism will surely falter in one degree or another; then, way will be given to anarchy, disorder, hatred and many other barbaric acts. This dimension of reconnection between humans can positively influence nature. Metaphorically, Gaudé advocates a humanist vision, which is not exclusively based on human relationships. He decries Moroccan soldiers' influence on nature, but from a contributory perspective, that is, he urges them to preserve nature (forest).

To the author, by destroying nature, they implicitly participate in the annihilation of human species, for nature contributes to the humans' formation: either by feeding or by curing diseases. To Cecilia M. Holmlund and Monica Hammer, "human societies benefit in numerous ways from ecosystem services generated by fish populations. Fish are part of food chain dynamics, nutrient cycling, and ecosystem resilience. Their mobility within the nested set of temporal and spatial cycles of ecological systems enhances the functional importance of fish as ecological memory in the form of energy, nutrients, genetic reserves, and information. Fish also generate employment, function as a genetic library for possible future use in medicine and aquaculture, stimulate human interest in nature, and provide aesthetic and recreational values" (Holmlund and Hammer, 1999). Clearly, nature determines human beings; it defines their existence. Better still, the density of the forests ensures good rainfall, which helps to balance aquatic environment. In that respect, Gaudé's novel advocates a reconnection between humans and nature. No one can deny such a project whose ideals help to avoid the worst to both entities (humans \& nature).

Further, human activities directly or indirectly influence nature. Indeed, by setting fire to the forest or abusively fishing aquatic animals, humans negatively influence their environment (nature). In Eldorado, human activities, which have direct negative impacts on nature, are numerous and they endanger humans' lives. From that point of view, Gaudé's literary project pleads for humanistic actions towards plant species and non-human animal communities, evolving in the sea. Analyzing the relevance of nature, Cecilia M. Holmlund \& Monica Hammer assert, "fish are generally valued for their qualities as goods, selected by human preferences, in the form of food protein, fishmeal, fish oil, game fish, and for aquaculture production. Also, in the pharmaceutical industry, certain substances from fish are used in research and might become important in the production of medicines" (Holmlund \& Hammer, 1999). Observably, aquatic resources are necessary for humans' lives. As to human activities, which indirectly destroy nature, we have waste. In fact, unrecycled waste is a threat to human health. Gaudé's novel advocates that attention should be paid to this management. This can be a success through a reasoned environmental policy. Implicitly, Eldorado challenges the municipal authorities of Catania and Lampedusa to take care of their cities. Moreover, Gaudé's novel sensitizes those who operate on Catanian market to be more respectful towards their environment. As we can notice, the author's humanism consists in considering nature from an altruistic perspective. His fictional work promotes moral values.

In terms of Christianist reconnection, it should be noted humans' peaceful attitude or actions towards others is the 
focus point of Christianist reconnection. In Eldorado, the priest of Lampedusa is described as a symbol of the metaphor of Christianist reconnection. Gaudé's narrator reveals, "the commander knew the history of these tombs. They were those of the first immigrants (...). The sea regularly brought them dead bodies and they were upset. These men, whose names, countries and histories they knew nothing about, came to their homes and their bodies could never be returned to their mothers. The priest of Lampedusa decided to bury those men as he would have done with his parishioners. He probably knew Muslims, but he planted crosses. Because that was all he knew how to do. Or perhaps because it was to his own God that he recommended them" (Translation mine) (Gaudé, 2006). From the preceding citation, one might ask the following question: what does this priest gain by burying the migrants' bodies whose identities and roots remain unknown?

Apparently, he obtains no reward; however, as God's representative, he acts in his name. Implicitly, Gaudé's novel teaches God's love. The priest acts an exemplary of fair love. Indeed, he shows a Christianist humanism, which honors him before his Lord. In other words, the priest of Lampedusa advocates fair love without compensation. He urges European and Moroccan authorities to treat migrants and nature with consideration.

\section{CONCLUSION}

In this study, our focus point was figurative disconnection. To analyze it, we identified various levels of disconnection. Firstly, we revealed the prevailing rupture between nature and humans, which is apparent through the unpleasant treatment inflicted upon nature (environment). Secondly, we examined the tumultuous relation between humans and the aquatic fauna, which is corroborated by the abusive exploitation of the halieutic resources. The contempt, which is drawn from the excessive exploitation of fish, was perceived as a symbol of the metaphor of disconnection. Thirdly, our study exposed Gaudé's ecological plea. Here, his humanism imbued with Christianist values was considered as a vehicle for reconciliation and reconnection. Through that humanism, we disclosed that Eldorado urges European authorities to reconsider their foreign and environmental policies. The use of the ecocritical approach made possible the analysis of the above values. From the same theoretical perspective, this study established that considering humans ensures plant, and animal values, balance among living beings are also ensured on the planet earth. By referring to those results, we can conclude that they have answered the questions raised by the topic under consideration. However, it should be noted that Gaudé's novel incorporates various other values, which the current study failed to address, because of the objective assigned to it and its reduced volume. In terms of new perspectives or orientations, themes such as silence, illusion, and the paradox of immigration might be noble axes of study.

\section{REFERENCES}

[1] Baage, S. U. (2017). Regards exotopiques sur deux portes de l'Europe: la crise migratoire à Lampedusa et à Mayotte dans Eldorado et Tropique de la violence. Carnets. $2^{\text {ème Série }-11 .}$ https://doi.org/10.4000/carnets.2369

[2] Flores C. (2019). The Disconnection between Humans and Nature. Retrieved August 12, 2021, from https://www. humansandnature. org /whathappens-when-we-see-ourselves-asseparate-fromor-as-a-part-of-nature-the-disconnection-betweenhumans-and-nature

[3] Gaudé, L. (2006). Eldorado. Paris, Actes Sud/Éditions Barzak.

[4] Glotfelty, C. \& Fromm, H. (1996). The Ecocriticism Reader Landmarks in Literary Ecology. Athens and London, The University of Georgia Press.

[5] Holmlund C. M. \& Hammer M. (1999). Ecosystem Services Generated by Fish Populations. Ecological Economics 29, pp. 253-268. Retrieved August 12, 2021, from DOI:10.1016/S0921-8009(99)00015-4

[6] Mole, G. D. (2019). Mordre la poussière dans l'Eldorado à rebours: Laurent Gaudé, la migration clandestine et l'ombre de Massambalo. The French Review, 93(2).

https://doi.org/10.1353/tfr.2019.0006

[7] Palud, A. (2020). Trajectoires contemporaines: traverser la Méditerranée dans le roman du XXIème siècle. Mémoire en jeu (Memories at Stake), Revue Critique Interdisciplinaire et Multiculturelle sur les Enjeux de Mémoire. https://www.memoires-enjeu.com/pedagogie/trajectoires-contemporainestraverser-la mediterranee-dans-le-roman-du-xxiesiecle/

[8] Tia, D. (2021). Contrast of Visions in Paule Marshall and Laurent Gaudé's Novels. International Journal of Social Science Studies, Redfame Publishing, Vol. 9(4), pp. 55-65, July. Retrieved August 4, 2021, from http://redfame.com/journal/index.php/ijsss/articl e/view/5279

[9] Vining J. (2003). The Connection to other Animals and Caring for Nature. Human Ecology Review, Vol. 10, No. 2, Special Issue: Conservation Psychology, pp. 87-99. Retrieved August 15, 2021, from https://www.jstor.org/stable/24706957 